\title{
Ophthalmic features of Turner's syndrome
}

\begin{abstract}
Turner's syndrome is one of the most common of all chromosomal abnormalities and is associated with significant ophthalmic morbidity. Turner's 1938 account included two patients with strabismus, and hitherto the condition has generated more interest among orthoptists than ophthalmologists. This systematic review of the literature seeks to redress the balance. Based on the pooled data of 274 patients with Turner's syndrome, it is the most complete evaluation so far of the prevalence and severity of ophthalmic problems in this population. This includes both a systematic review of the ophthalmic literature (via Medline) and the much larger body of work available in the orthoptic literature. Finally, we consider recent progress that enables the ophthalmologist to progress from the simple recognition of a phenotype to the correlation of genotypic variations with embryogenesis and consequent features of that phenotype.

Eye (2004) 18, 680-684. doi:10.1038/sj.eye.6701323

Published online 27 February 2004
\end{abstract}

Keywords: Turner's syndrome; $\mathrm{X}$ chromosome; mosaicism

\section{Department of}

Ophthalmology

Birmingham and Midland Eye Centre, City Hospital Birmingham, UK

Correspondence: AKO Denniston Department of Ophthalmology Birmingham and Midland Eye Centre, City Hospital Dudley Road, Birmingham B18 7QU, UK

Tel: + 1215543801

Fax: + 1215543801

E-mail: alastair@

denniston.org

Published online:

27 February 2004

\section{Introduction}

Turner's syndrome is a chromosomal abnormality, affecting about 1 in 2000 live female births. ${ }^{1}$ Although it is associated with significant ophthalmic morbidity, this is usually underestimated and often goes unrecognised. Delay in orthoptic and ophthalmic input increases the risk of amblyopia and long-term visual impairment. This review considers the genetics, diagnosis, and management of Turner's syndrome.

Turner's syndrome has been recognised since the 1930s when Otto Ullrich and Henry Turner described female subjects with the association of short stature, sexual infantilism, webbed neck, and cubitus valgus. ${ }^{2}$ The first description, at least of primary ovarian failure, was probably by Morgagni in $1761 .{ }^{3}$ However, it was not until 1959 that the chromosomal nature of the condition was described.

\section{Genetics and Pathogenesis}

Turner's syndrome is best known for the $\mathrm{XO}$ karyotype, more accurately described as $45, X$. In fact, this represents only half the patients with Turner's syndrome. A further 15\% are mosaics having both $45, X$ and a normal cell line, that is, $45, X / 46, X X$. The remainder demonstrates a range of abnormalities of the $X$ chromosome including partial deletions and ring chromosomes. In the majority of cases $(60 \%)$, it is the paternal $\mathrm{X}$ chromosome that has been lost during meiosis. As yet, no risk factors for this chromosomal loss have been identified; maternal age is not a risk factor. ${ }^{4}$ The $45, X$ karyotype arises in $3 \%$ of all conceptions, but results in spontaneous abortion in $99 \%$ of cases.

The Turner's phenotype arises from X-linked genes that escape inactivation. Important among these are the short-stature-homeobox (SHOX) gene, mutations of which result in such well-recognised features like short stature and Madelung deformity (a skeletal abnormality of the distal forearm). ${ }^{5,6}$ Candidates for causing the gonadal dysgenesis include USP9X, RPS4X, and DIAPH2. USP9X is of particular ophthalmic interest since its homologue in Drosophila (fruit fly) is involved in the development of the eye as well as the ovary. ${ }^{7,8}$

\section{Systemic features}

The normal foetal ovary contains 7 million oocytes that rapidly reduce to 2 million at birth, 500000 at menarche and 10000 at menopause. In Turner's syndrome, this appears to be accelerated so that by 2 years of age, there are almost no oocytes left. This premature gonadal aging results in 'streak' ovaries. Consequently, there is delay or failure of puberty, amenorrhoea, and infertility. ${ }^{9,10}$ Interestingly, 
the rare instances of pregnancy that do occur show increased rates of chromosomal aberrations such as trisomy 21 (Down's syndrome) and, in one case, an identical Turner's karyotype to the mother. ${ }^{11,12}$

Short stature is almost universal. ${ }^{13}$ Additional features are common ${ }^{14-20}$ and are listed in Table 1. Interestingly, the individual's phenotype appears to be dependent on the exact genotype and even the parental origin of the remaining $X$ chromosome. For example, although intelligence is normal in most patients, those with the ring $X$ chromosome (ie 45, X/46, $X, r(X)$ ) do show mental retardation. ${ }^{21}$ Additionally, those who have inherited a paternal X chromosome $(45, \mathrm{Xp})$ appear to do well with regard to social adjustment, verbal and executive function skills but relatively poorly on visuospatial memory tests. In contrast, those with a maternal $X$ chromosome $(45, \mathrm{Xm})$ did well with regard to visuospatial memory, but poorly with verbal memory. ${ }^{22,23}$

\section{Ocular features}

Ocular abnormalities are common in this syndrome, but are underestimated and often neglected. Only two case series have been published in the ophthalmic literature $^{24,25}$ representing a total of 54 patients. However, search of the orthoptic literature revealed a further four series that contribute another 220 patients. ${ }^{26-29}$ The results of these series are collected in Table 2 and the pooled data analysed.

Table 1 Systemic features of Turner's syndrome

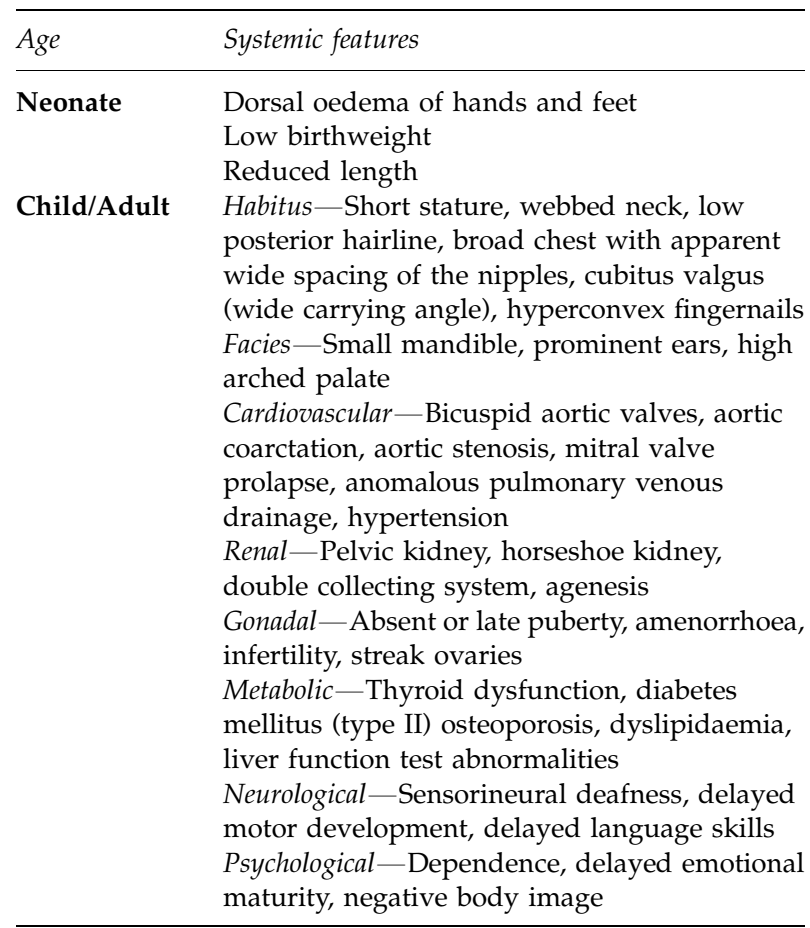

Table 2 Cumulative ophthalmic and orthoptic case-series of patients with Turner's syndrome

\begin{tabular}{|c|c|c|c|c|c|c|c|c|}
\hline Series & Wesson $^{26}$ & $\operatorname{Raab}^{27}$ & Troupe $^{28}$ & Adhikary $^{25}$ & Chrousos $^{24}$ & Masters $^{29}$ & Total & $\%$ \\
\hline Year & 1974 & 1974 & 1981 & 1981 & 1984 & 1990 & 2003 & \\
\hline$N$ & 11 & 7 & 25 & 24 & 30 & 177 & 274 & \\
\hline Genetics if known & & $5 \mathrm{XO}$ & & $15 \times O$ & $23 \times \mathrm{O}$ & & & \\
\hline$($ mosaic $=m)$ & & $+2 \mathrm{~m}$ & & $+5 \mathrm{~m}$ & $+7 \mathrm{~m}$ & & & \\
\hline Amblyopia & & $1 / 7$ & & $10 / 24$ & $4 / 30$ & $30 / 95$ & $45 / 156$ & $29 \%$ \\
\hline Strabismus & $5 / 11$ & $3 / 7$ & $6 / 25$ & $9 / 24$ & $10 / 30$ & $58 / 177$ & $77 / 274$ & $33 \%$ \\
\hline Phoria only & $3 / 11$ & $2 / 7$ & $13 / 25$ & & & $49 / 104$ & $67 / 147$ & $46 \%$ \\
\hline Exotropia & $2 / 11$ & $1 / 7$ & $5 / 25$ & $1 / 24$ & $2 / 30$ & $12 / 166$ & $23 / 263$ & $9 \%$ \\
\hline Esotropia & $2 / 11$ & $1 / 7$ & $1 / 25$ & $8 / 24$ & $8 / 30$ & $33 / 166$ & $53 / 263$ & $20 \%$ \\
\hline Hypertropia & $2 / 11$ & $1 / 7$ & $0 / 25$ & $0 / 24$ & $0 / 30$ & $6 / 166$ & $9 / 263$ & $3 \%$ \\
\hline Hypermetropia & $2 / 11$ & & & $10 / 24$ & $5 / 30$ & $48 / 177$ & $65 / 242$ & $27 \%$ \\
\hline Myopia & & & & & & $23 / 177$ & $23 / 177$ & $13 \%$ \\
\hline Reduced accommodation & & $5 / 5$ & & & & $27 / 76$ & $32 / 81$ & $40 \%$ \\
\hline Convergence insufficiency & $9 / 11$ & & $15 / 25$ & & & $32 / 104$ & $56 / 140$ & $40 \%$ \\
\hline Nystagmus & & & & & $1 / 30$ & $11 / 104$ & $12 / 134$ & $9 \%$ \\
\hline Ptosis & & & & $7 / 24$ & $5 / 30$ & $34 / 165$ & $46 / 219$ & $21 \%$ \\
\hline Epicanthus & & & & $11 / 24$ & $3 / 30$ & $42 / 104$ & $56 / 158$ & $35 \%$ \\
\hline Hypertelorism & & & & & $3 / 30$ & & $3 / 30$ & $10 \%$ \\
\hline Antimongoloid palpebral fissures & $2 / 11$ & & & & $3 / 28$ & $3 / 47$ & $8 / 86$ & $9 \%$ \\
\hline Red-green deficiency & $3 / 9$ & & $1 / 25$ & & $3 / 30$ & $13 / 177$ & $20 / 241$ & $8 \%$ \\
\hline Presenile cataract & & & & $1 / 24$ & $0 / 30$ & $2 / 42$ & $3 / 96$ & $3 \%$ \\
\hline Congenital glaucoma & & & & $0 / 24$ & $0 / 30$ & $1 / 42$ & $1 / 96$ & $1 \%$ \\
\hline Blue sclera & & & & $0 / 24$ & $0 / 30$ & $2 / 42$ & $2 / 96$ & $2 \%$ \\
\hline
\end{tabular}

Horizontal and vertical tropias may coexist and thus sum to more than total strabismus. Some of the orthoptic studies only collected eye movement data resulting in more limited data for other ocular features. 
The cumulative data shown here now permit more accurate estimation of the prevalence of ophthalmic morbidity in the Turner's syndrome population. For some of the features considered, the existing measures are satisfactory. For example, although ametropia is very common (around 40\%), this is probably adequately dealt with by community optometrists. However, the high rate of amblyopia (almost 30\%) and strabismus (33\%) is of greater concern. There is a danger that parents and community doctors may concentrate exclusively on the 'medical' features of Turner's syndrome, resulting in delayed recognition of strabismus and developing amblyopia. The high prevalence of these conditions would argue for early systematic screening of children with Turner's syndrome. This could initially be by orthoptists with appropriate onward referral to an ophthalmologist.

Numerous case reports ${ }^{30-35}$ have suggested additional associations (Table 3). While of interest, such isolated associations may arise by chance and cannot determine the frequency or significance of any association.

It is important to realise that classical X-linked recessive disease may occur in the Turner's female. This may be a trap for the unwary ophthalmologist who rules out a diagnosis on the basis of gender. This is demonstrated by the high prevalence of colour vision abnormalities (8\%), which is at a level typical of the male, rather than the female, population. In addition, the authors know of patients with Turner's syndrome and Xlinked congenital stationary night blindness, and of Turner's with Duchenne's muscular dystrophy.

Table 3 Ocular features of Turner's syndrome

\begin{tabular}{|c|c|}
\hline From pooled case series & $\begin{array}{l}\text { Additional features } \\
\text { in case reports }\end{array}$ \\
\hline $\begin{array}{l}\text { Common (>25\%) } \\
\text { Amblyopia } \\
\text { Strabismus } \\
\text { Reduced accommodation } \\
\text { Convergence insufficiency } \\
\text { Uncommon (5-25\%) } \\
\text { Ptosis } \\
\text { Epicanthus } \\
\text { Hypertelorism } \\
\text { Antimongoloid } \\
\text { palpebral fissures } \\
\text { Red-green deficiency } \\
\text { (male incidence) } \\
\text { Nystagmus }\end{array}$ & $\begin{array}{l}\text { Conjunctival lymphoedema } \\
\text { Keratoconus }^{33} \\
\text { Anterior segment dysgenesis }^{37} \\
\text { Anterior lenticonus } \\
\text { Retinal neovascularization } \\
\text { Choroidal neovascular }^{35} \\
\text { membrane }^{35} \\
\text { Retinal detachment }^{32}\end{array}$ \\
\hline $\begin{array}{l}\text { Rare }(<5 \%) \\
\text { Presenile cataract } \\
\text { Congenital glaucoma } \\
\text { Blue sclera }\end{array}$ & \\
\hline
\end{tabular}

Hitherto few reports have provided detailed karyotypic information. As karyotype and genetic analysis improves it may become possible to more accurately match ophthalmic phenotype with an individual's genotype (akin to the relative success with systemic phenotype/genotype matching ${ }^{35}$ ). One thorough ophthalmic and chromosomal examination of four girls with mosaic Turner's syndrome demonstrated anterior segment abnormalities including glaucoma and abnormal irides (Rieger malformation). Interestingly, although mosaicism was observed in all four cases, there was variation in the cell line type, that is, with residual $\mathrm{Y}$ chromosome material $(45, \mathrm{X} /$ $46, X, \operatorname{idic}(Y))$ in two cases, with a ring $X$ chromsome $(46, X, r(X))$ in another and with an extra $X$ chromsome $(47, X X X)$ in the fourth. Given this variation in karyotype the authors speculate as to whether it is the direct effect of mosaicism per se on the embryogenesis of the anterior segment that gives rise to these abnormalities. $^{36,37}$

\section{Management}

Patients with Turner's syndrome require multidisciplinary care. This is normally coordinated by a paediatrician, with appropriate input from endocrinologists, cardiologists, nephrologists, psychologists, and others. Valuable support and information for patients and their families are available from the Turner Syndrome Support Society (www.tss.org.uk).

As discussed above, the prevalence of ocular morbidity would argue for greater routine ophthalmic input, for example early orthoptic screening with onward referral to an ophthalmologist where indicated. General treatment strategies include hormone replacement (both growth hormone and oestrogen), This may impact the ophthalmologist since concern has been voiced over possible ophthalmic sequelae. Koller et al ${ }^{38}$ reported two non diabetic patients with Turner's syndrome who developed retinal changes mimicking diabetic retinopathy when treated with growth hormone. The authors note previous hypotheses suggesting a role for growth hormone in the pathogenesis of diabetic retinopathy. However, neovascular changes may be seen in Turner's syndrome in the absence of exogenous growth hormone. ${ }^{33}$ It should also be noted that the increased prevalence of type II diabetes mellitus (with attendant ophthalmic complications) in Turner's population requires care in regard to exogenous growth hormone and monitoring of glycaemic tolerance. ${ }^{18,39}$ 


\section{Conclusion}

An increased awareness of the ophthalmic features of Turner's syndrome should enable earlier detection and treatment of sight-threatening conditions. This review provides a more accurate estimate of the prevalence and severity of the ophthalmic sequelae of this syndrome. Recent advances in the understanding of this condition are enabling progression from a simple description of a syndrome to the correlation of genotypic variations with embryogenesis and consequent features of that phenotype.

\section{References}

1 Hsu LYF. Prenatal diagnosis of chromosomal abnormalities through amniocentesis. In: Mulinsky A (ed). Genetic Disorders and the Fetus. Johns Hopkins University Press: Baltimore, MD, 1998, pp 179-248.

2 Turner HH. A syndrome of infantilism, congenital webbed neck and cubitus valgus. Endocrinology 1938; 23: 566-574.

3 Moore KL The Sex Chromatin. WB Saunders: Philadelphia, PA, 1966.

4 Mathur A, Stekol L, Schatz D, MacLaren NK, Scott ML, Lippe B. The parental origin of the single $\mathrm{X}$ chromosome in Turner syndrome: lack of correlation with parental age or clinical phenotype. Am J Hum Genet 1991; 48: 682-686.

5 Rao E, Weiss B, Fukami M et al. Pseudoautosomal deletions encompassing a novel homeobox gene causing growth failure in idiopathic short stature and Turner syndrome. Nat Genet 1997; 16: 54-63.

6 Clement Jones M, Schiller S, Rao E, Blaschke RJ, Zuniga A, Zeller $\mathrm{R}$ et al. The short stature homeobox gene SHOX is involved in skeletal abnormalities in Turner syndrome. Hum Mol Genet 2000; 9: 695-702.

7 Ogata T, Matsuo N. Sex chromosome aberrations and stature: deduction of the principal factors involved in the determination of adult height. Hum Genet 1993; 91: 551-562.

8 Zinn AR, Ross JL. Critical regions for Turner syndrome phenotypes on the $\mathrm{X}$ chromosome. In: Saenger P, Pasquino AM (eds). Optimizing Health Care for Turner Patients in the 21st Century. Elsevier: Amsterdam, 2000, pp 285-294.

9 Pasquino AM, Pucarelli I, Segni M. Spontaneous puberty in Turner syndrome. In: Saenger P, Pasquino AM (eds). Optimizing Health Care for Turner Patients in the 21st century. Elsevier: Amsterdam, 2000, pp 285-294.

10 Tilly JL, Morita Y, Maravei DV, Matikainen T, Perez GI Genetic control of oocytes. In: Saenger P, Pasquino AM (eds ). Optimizing Health Care for Turner Patients in the 21st century. Elsevier: Amsterdam, 2000, pp 285-294.

11 Tarani L, Lampariello S, Raguso G, Colloridi F, Pucarelli I, Pasquino AM et al. Pregnancy in patients with Turner's syndrome: six new cases and review of the literature. Gynecol Endocrinol 1998; 12: 83-87.

12 Blumenthal AL, Allanson JE. Turner syndrome in a mother and daughter: $r(X)$ and fertility. Clin Genet 1997; 52: 187.

13 Ranke MB, Grauer ML. Adult height in Turner syndrome: results of a multinational survey 1993. Horm Res 1994; 42: 90-94.

14 Rapaport R. Hypofunction of the ovaries: Turner syndrome. In: Behrman RE, Kliegman RM, Jenson HB (eds). Nelson's
Textook of Pediatrics 16th ed. WB Saunders: Philadelphia, PA, 2000, pp 1753-1755.

15 Lin AE, Lippe B, Rosenfield RD. Further delineation of aortic dilation, dissection and rupture in patients with Turner's syndrome. Pediatrics 1998; 102: e12.

16 Sybert VP. Cardiovascular malformations and complications in Turner syndrome. Pediatrics 1998; 101: 111-117.

17 de Kerdanet M, Lucas J, Lemee F, Lecornu M. Turner's syndrome with $\mathrm{X}$-isochromosome and Hashimoto's thyroiditis. Clin Endocrinol Oxf 1994; 41: 673-676.

18 Radetti G, Mazzanti L, Paganini C, Bernasconi S, Russo G, Rigon $\mathrm{F}$ et al. Frequency, clinical and laboratory features of thyroiditis in girls with Turner's syndrome. The Italian Study Group for Turner's Syndrome. Acta Paediatr 1995; 84: 909-912.

19 Gravholt CH, Juul S, Naeraa RW, Hansen J. Morbidity in Turner Syndrome. J Clin Epidemiol 1998; 51: 147-158.

20 Albareda MM, Gallego A, Enriquez J, Rodriguez JL, Webb SM. Biochemical liver abnormalities in Turner's syndrome. Eur J Gastroenterol Hepatol 1999; 11: 1037-1039.

21 Migeon BR, Luo S, Jani M, Jeppeson P. The severe phenotype of females with tiny ring $\mathrm{X}$ chromsomes are associated with inability of these chromosomes to undergo X inactivation. Am J Med Genet 1994; 55: 497.

22 Skuse DH, James RS, Bishop DVM, Coppin B, Dalton P, Aamodt-Leeper $\mathrm{G}$ et al. Evidence from Turner's syndrome of an imprinted X-linked locus affecting cognitive function. Nature 1997; 387: 705-708.

23 Bishop DVM, Canning E, Elgar K, Morris E, Jacobs PA, Skuse DH. Distinctive patterns of memory function in subgroups of females with Turner syndrome: evidence for imprinted loci on the $\mathrm{X}$-chromosome affecting neurodevelopment. Neuropsychol 2000; 38: 712-721.

24 Chrousos GA, Ross JL, Chrousos G, Chu FC, Kenigsberg D, Cutler Jr G et al. Ocular findings in Turner syndrome. A prospective study. Ophthalmology 1984; 91(8): 926-928.

25 Adhikary HP. Ocular manifestation of Turner's syndrome. Trans Ophtalmol Soc UK 1981; 101 (Part 4): 395-396.

26 Wesson ME. Turner's syndrome. Am Orthoptics J 1971; 21: 50-56.

27 Raab EL. Discussion on Turner's syndrome. Am Orthoptics J 1971; 21: 56-57.

28 Troupe JT, Troupe CC. Evaluation of strabismus in Turner's syndrome. In: Mein J, Moore S (eds). Transactions of the Fourth International Orthoptic Congress. Kimpton: London, 1981, pp 127-130.

29 Masters MC. Eyes and the Turner syndrome: a nationwide survey. Br Orthoptics J 1990; 46: 6-17.

30 Kapoor S, Dasgupta J. Chromosomal anomaly in a female patient with anterior lenticonus. Ophthalmologica 1979; 179: 271-275.

31 Perry HD, Cossari AJ. Chronic lymphangiectasis in Turner's syndrome. Br J Ophthalmol 1986; 70: 396-399.

32 Mason III JO, Tasman W. Turner's syndrome associated with bilateral retinal detachments. Am J Ophthalmol 1996; 122: 742-743.

33 Macsai M, Maguen E, Nucci P. Keratoconus and Turner's syndrome. Cornea 1997; 16: 534-536.

34 Gotoh M, Yamamoto M, Kawasaki T, Shigetoh M, Inomota $\mathrm{H}$. Two cases of unilateral retinal neovscularization in Turner syndrome. Am J Ophthalmol 1998; 126: 144-146. 
35 Beatty S, Black G, Rhatigan M, Bishp P. Bilateral subfoveal choroidal neovascularization in Turner's syndrome: coincidence or consequence? Can J Ophthalmol 1999; 34: 346-348.

36 Ranke MB, Saenger P. Turner's syndrome. The Lancet 2001; 358: 309-313.

37 Lloyd IC, Haigh PM, Clayton-Smith J, Clayton P, Price DA, Ridgway AEA et al. Anterior segment dysgenesis in mosaic Turner syndrome. Br J Ophthalmol 1997; 81: 639-643.
38 Koller EA, Green L, Gertner JM, Bost M, Malozowski SN Retinal changes mimicking diabetic retinopathy in two nondiabetic, growth hormone-treated patients. J Clin Endocrinol Metab 1998; 83(7): 2380-2383.

39 Gravholt CH, Naeraa RW, Nyholm B, Gerdes LU, Christiansen E, Schmitz O et al. Glucose metabolism, lipid metabolism and cardiovascular risk factors in adult Turner syndrome. The impact of sex hormone replacement. Diabetes Care 1998; 21: 1062-1070. 